\title{
An Investigation into Major Causes for Postharvest Losses of Horticultural Crops and Their Handling Practice in Debre Markos, North-Western Ethiopia
}

\author{
Yebirzaf Yeshiwas $\mathbb{D}^{1}$ and Esubalew Tadele $\mathbb{D}^{2}$ \\ ${ }^{1}$ Debre Markos University, College of Agriculture, Department of Horticulture, Debre Markos, Ethiopia \\ ${ }^{2}$ Department of Agricultural Economics, College of Agriculture, Debre Markos University, Debre Markos, Ethiopia \\ Correspondence should be addressed to Yebirzaf Yeshiwas; yebirzaf80@yahoo.com
}

Received 10 July 2021; Revised 15 August 2021; Accepted 26 August 2021; Published 6 September 2021

Academic Editor: Yunchao Tang

Copyright (C) 2021 Yebirzaf Yeshiwas and Esubalew Tadele. This is an open access article distributed under the Creative Commons Attribution License, which permits unrestricted use, distribution, and reproduction in any medium, provided the original work is properly cited.

In developing countries, food systems are mainly characterized by unorganized, traditional supply chains, and limited market infrastructure. Bulk quantity of the harvested produce is lost every year because of the absence of proper postharvest handling and management practices. The current study was conducted to estimate and identify the major causes for postharvest losses of fruits and vegetables in Debre Markos, north-western Ethiopia. Forty respondents who were retailing fruits and vegetables were randomly selected and qualitative and quantitative data were collected by using direct market observation and semistructured questioners. The result of the present study revealed significant differences between sociodemographic factors, handling practices, and postharvest loss. Educational status, selling experience, and packaging material have a significant relationship with postharvest loss. A significant difference was obtained among the transportation methods used, the selling place, storage methods, and materials. The result also indicated that fewer than 20 percent of respondents practiced selling fruits and vegetables in the resident mini shop. The majority of damaged produce was sold at a discount price. Retailers do not have formal knowledge of postharvest handling practices. The average postharvest losses of fruits and vegetables were estimated to be five to eighty-three percent of the market share. Mainly, during retailing, rotting, mechanical damage, poor handling, improper management of temperature and relative humidity, and hygiene problems during handling are among the major causes of postharvest losses. To reduce the high postharvest loss and supply quality products for consumers throughout the year, intervention activities such as the construction of permanent selling place for perishables, practicing various evaporative cooling technologies, outset training, awareness creation, and infrastructures should be effectively and urgently addressed.

\section{Introduction}

By 2050, the world's population is projected to surpass 10 billion and will require a 70 percent increase in food production $[1,2]$. Hence, feeding a global population becomes one of the highest challenges. Likewise, FAO [3] indicated that, in developing countries, nearly 870 million people were suffering from food and nutrition insecurity during the year 2010-2012. In recent years, an increase in malnutrition has taken place in North Africa, Sub-Saharan Africa, and Western Asia. Particularly, in Sub-Saharan Africa, about 27 percent or 234 million people did not get sufficient food [3].
Ethiopia in general and the North Western part of the country specifically are exposed to severe food insecurity and poverty [4].

Horticultural crops, especially fruits and vegetables remain very important for ensuring food and nutritional security [5]. Ethiopia has a comparative advantage in many fruit and vegetable crops production due to the availability of cheap labor, proximity to the export market, its favorable weather condition, and diverse agroecology which makes it suitable to produce a variety of horticultural crops $[6,7]$.

In the $2017 / 2018$ cropping season, the area covered by fruits and vegetables was about 0.55 million hectares with 
more than 60.78 tons of harvest [8]. However, a large proportion of the harvested produce did not reach the end consumers because of the limited postharvest handling and management practices. Every year, bulk quantities of the harvested produce is lost by different factors. Practically, farmers were forced to sell their hard-earned produce at low and unsatisfactory prices due to a lack of storage infrastructures and marketing facilities and seasonal gluts. Moreover, lack of postharvest management practices diminishes food availability and hence market opportunities and causes a decline in income opportunities due to high physical loss. Studies verified that, instead of increasing food production, reducing postharvest loss can save scarce resources and the environment [9]. Therefore, reducing the loss of fresh products after harvest is an essential approach for better food availability [10].

According to Madrid [11], a large portion of the freshly harvested produce was lost worldwide after harvest due to different reasons. In developing countries, losses are estimated from 20 to 40 percent, whereas they are 10 to 15 percent in developed countries, depending on the season of production and commodities nature [11-13]. It is estimated that postharvest losses in developed countries are of an average of 12 percent to 20 percent from production retail warehouses to foodservice sites [11]. However, losses in developing countries are even higher because of poor storage and food-handling technologies [14].

Fresh harvested horticultural crops are living plant parts that continue their living processes even after detachment. Thus, they contain a high amount of water, respire more, generate heat, and are subject to desiccation and mechanical injury. Their storage period and shelf-life depend on the rate of utilization of their stored food reserves and the rate of transpiration. After exhaustion of stored food, the produce deteriorates. Hence, such perishable commodities require proper handling at harvest and after the harvesting period. Thus, deterioration of produce is minimized in the period between harvest and consumption through proper handling, storage, and management to satisfy the market requirement and to minimizes their losses.

In Ethiopia, inappropriate management of fresh horticultural crops and poor marketing method causes enormous losses after harvest on the points of transportation, marketing, and storage. Thus, proper management of harvested commodities is essential to reduce postharvest losses and their nutritional improvement, food security, and employment opportunity. To satisfy the demand in existing production, reducing the postharvest losses and maintaining its quality are vital. In our investigation area, huge quantities of fruits and vegetables deteriorated and are lost. Therefore, the present study estimates the postharvest loss of fruits and vegetables and identifies the major causes for postharvest losses in, Northwestern Ethiopia, in the case of Debre Markos.

\section{Material and Methods}

2.1. Area Description. The study was held at Debre Markos city administration, East Gojjam zone. It is found $300 \mathrm{ki}-$ lometers of North-western Addis Ababa, the capital city, and
265 kilometers South-East of the regional state capital, Bahir Dar. It is geographically located at $10^{\circ} 20^{\prime} \mathrm{N} 37^{\circ} 43^{\prime} \mathrm{E}$ (Figure 1). It is located at 2450 m.a.s.l. The area receives an average annual rainfall of $1300-1380 \mathrm{~mm}$ and the temperature varies from $15^{\circ} \mathrm{C}$ to $22^{\circ} \mathrm{C}$ based on the 2007 national survey, the total population of the town was 62,469 with a total of 18,479 households [15].

2.2. Sampling and Method of Data Collection. Our sampling unit was individuals who retail fruits and vegetables in Debre Markos town from June 2019 to November 2019. Forty representative respondents were randomly selected among fruit and vegetable retailers by a simple random sampling method taking consideration of a random portion of the entire retailers to represent the entire data set, where each retailer has an equal probability of being chosen.

This study, therefore, refers to Yamane [16] that provided a simplified estimator to draw sample sizes as

$$
n=\frac{N}{1+N(e)^{2}},
$$

where $n$ is the required sample size, $N$ is the target population size (total retailers were 85 ), and $e$ is the precision level (5\%).

Our representative sample size $n=\left(85 / 1+85(0.05)^{2}\right)$ $=70$; however, we limit our sample to 40 based on respondents willing to reply (consent and making in-depth interviews).

The collected data were both of qualitative and quantitative nature from primary and secondary sources. The primary data sources were informant interviews and semistructured questionnaires using both open- and closeended questions. The closed-ended questions were designed to select an appropriate response and the open-ended questions were designed to allowing the respondents to freely express their thoughts. Informed consent from the respondents was assured during the interview. Fruit crops, such as sweet orange (Citrus sinensis), lime (Citrus aurantifolia), banana (Musa spp.), papaya (Carica papaya), citron (Citrus medica), and mango (Mangifera indica), and vegetable crops, such as onion (Allium cepa), kale (Brassica oleracea), head cabbage (Brassica oleracea var. capitata), green pepper (capsicum annum), Swiss chard (Beta vulgaris), potato (Solanum tuberosum), tomato (Lycopersicon esculentum), and carrot (Daucus carota), were assessed during the study period. Sample fruits were collected from the market and stored for 10 days at room temperature in the laboratory and types of causes for postharvest loss were recorded. Secondary data were emphasized using document analysis techniques and systematic review of peer-reviewed literature.

2.3. Data Analysis. We have used SPSS version 16.0 and SAS version 9.0 statistical software for descriptive and inferential statistics applied for this investigation. Both descriptive and inferential statistics were employed to predict and indicate the lost harvest and estimate the major causes for its loss in 


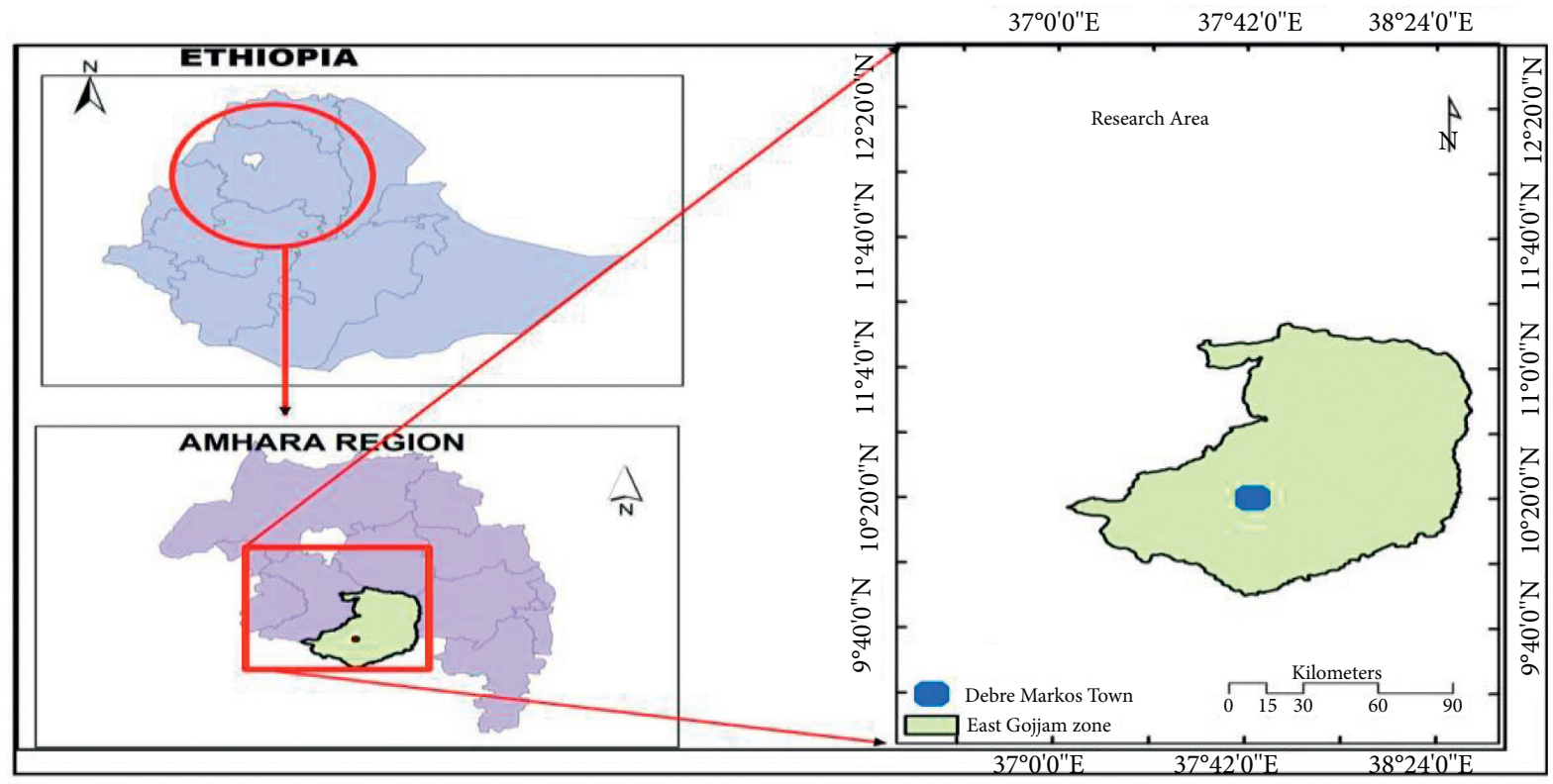

Figure 1: Location of the study area.

our investigation area. Descriptive analysis was realized to describe the sociodemographic profile and postharvest handling activities using frequency, mean, and percentage. Furthermore, inferential statistics (using Chi-square test) were implemented to explore the significant association between the sociodemographic aspects and fruits and vegetables postharvest losses.

\section{Results and Discussions}

3.1. Sociodemographic Characteristics. The result of the present finding indicated that eighty-five percent of females and fifteen percent of males were engaged in fruit and vegetable retailing business in Debre Markos town. Seventy percent of respondents are within the 36-40-year-old and $15 \%$ of respondents are within 31-35-year-old range. Regarding the informant's educational status, out of 40 respondents, $22(55 \%)$ had learned their secondary school (grades 7-10). On the other hand, 2 respondents (5\%) were illiterate (Table 1). Therefore, the dominant fruit and vegetable retailers in the study area are youths and educated persons and currently, it creates employment opportunities for the jobless youths.

3.2. Sociodemographic Features, Handlings Practices, and Postharvest Loss. The result of the Chi-square test indicated that there is a significant difference among educational status, selling experience, selling duration, packaging material, and postharvest loss. Thus, postharvest losses are dependent on fruit and vegetable seller's educational status, selling experience, packaging material. However postharvest loss is not significant for sex and age of fruit and vegetable retailers (Table 2).

The age of retailers does not significantly influence $\left(X^{2}=0.5528, p=0.4572\right)$ the postharvest loss of fruits and vegetables. Similar results were reported by Masood [17] who reported age and postharvest loss have no significant relationship. Gender had also a nonsignificant influence on postharvest loss. The reason could be due to the fact that the majority of fruit and vegetable retailers in the study area were literate and youth. The result is in contrast with the findings of Abera et al. [18] who explained that gender has a significant contribution to the postharvest loss of tomatoes.

The present study also indicated that educational status has (X2 $=8.9422$ and $p=0.0301)$ a significant influence on the loss of horticultural crops after harvest. When the educational status and selling experience of the retailers increase, the loss of fruits and vegetables decreases. Masood [17] and Alemayehu et al. [19] reported similar results as formal education has a significant contribution to the postharvest loss.

Chi-square analysis result also indicated that selling experience has a significant $\left(X^{2}=9.5426 p=0.0489\right)$ relationship with postharvest loss. The reason could be due to the experience they had which improved their awareness about handling methods of harvested fruits and vegetables. The packaging material during transporting and storing has also a significant effect on fruits and vegetables' loss after harvest. There is a significant difference $(p<0.0001)$ between selling duration and the loss after harvest. In the study area, the selling duration of harvested commodities depends on the amount they received or purchased for retail. When they receive a smaller quantity, there will be a shorter storage duration to sell the products and vice-versa. The majority of retailers sell their products at roadside/open space areas where the temperature is high which hastens the rate of deterioration of perishables after harvest. The results agreed with those of Kereth et al. [20] and Adugna et al. (2015). The deteriorate rate of harvested fresh commodities increases as they stay for a long time in the market, as their exposure to sunlight and fluctuated environmental conditions ultimately changes their aroma, texture, and flavor [20]. 
TABLE 1: Sociodemographic characteristics.

\begin{tabular}{lccc}
\hline Questioners & Status & Frequency & \\
& Illiterate & 2 & 5.0 \\
Educational status & Read and write only & 10 & 6 \\
& Grades 1-6 & 25.0 & 15.0 \\
& Grades 7-10 & 22 & 55.0 \\
\hline
\end{tabular}

Source: own survey (2019), where \% is percentage.

TABLE 2: Chi-square result for losses of fruits and vegetables after harvest and sociodemographic factors and postharvest handlings activities.

\begin{tabular}{lccc}
\hline Variable & $X^{2}$ & d.f. & $p$ value \\
\hline Gender & 0.4293 & 1 & $0.5124^{\text {ns }}$ \\
Age & 0.5528 & 1 & $0.4572^{\text {ns }}$ \\
Educational status & 8.9422 & 3 & $0.0301^{*}$ \\
Selling experience & 9.5426 & 4 & $0.0489^{*}$ \\
Packaging material & 11.6585 & 2 & $0.0086^{* *}$ \\
Selling duration & 22.1574 & 2 & $<0.0001^{* * *}$ \\
\hline
\end{tabular}

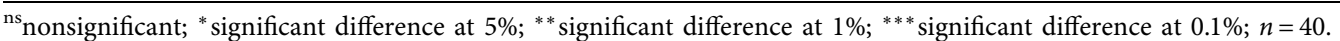

3.3. Source of Fruits and Vegetables. Fruit and vegetable retailers in Debre Markos town purchase the product from wholesalers, nearby farm sites and directly from producers. The present study indicated that $65 \%$ of respondents purchase the product from both wholesalers and producers followed by wholesalers alone (15\%) and producers alone (10\%) (Table 3).

3.4. Types of Packaging Materials Used. A highly significant ( $p=0.0004)$ difference between packaging materials used in the study area was observed. Around 35 percent of fruit and vegetable retailers used sacks alone and sacks and baskets together to pack and transport, followed by basket packaging material (20 percent), though the lowest (10 percent) applicable packaging material in fruit and vegetable retailers in the study area was by using wooden boxes (Figure 2). The reason for the use of sacks and baskets as major packaging material was their accessibility and low cost. However, such kind of packaging materials does not properly protect the product and causes mechanical damage and bruising. The use of inappropriate packaging material is a basic factor most regularly related to the maximum level of losses after harvest [21-23]. The result is in agreement with the finding of Adugna et al. [24]; they stated that more than $50 \%$ of the respondents use sacks as a packing material and people were not experienced in using a wooden box as a packing material at Jimma district. Likely, Yigzaw et al. [25] reported that retailers at Bahir Dar town transported and stored mango and sweet orange fruits by using sacks as a packaging material. Seid et al. [26] also reported, in South Wollo district, Ethiopia, that sacks are used as the major packaging material. Kereth et al. [20] reported that the use of sacks does not protect freshly harvested commodities from damage. Kader and Rolle [27] also explained that using sack containers for fruits and vegetables creates high heat because of metabolic reaction which ultimately hastens mechanical damage and microbial attack.
3.5. Transportation Method. Fruit and vegetable retailers in the study area purchase the product from nearby farmers and wholesalers and transport them by using different transportation methods. A highly significant difference $(p<0.0001)$ was obtained among the transportation methods used. The present study indicated that 55 percent of respondents have transported fruits and vegetables by using hand-drawn gharry followed by both hand-drawn gharry and human back/head, 40 percent, while the remaining 5 percent of respondents were using the head/back of humans as transportation method (Figure 3). Tesfaye [7] explained that transportation of harvested fruits and vegetables needs well-organized services to be accessible on the harvested place to transport produce as quickly as possible with minimum damage. Rehman et al. [28] reported that fruits and vegetables should be transported by proper transportation and packaging systems to reduce damage.

3.6. Marketing/Selling Places. A highly significant difference $(p<0.0001)$ was observed in the selling places of fresh fruits and vegetables. The present finding indicated that all respondents were displaying and selling guava and citron on open spaces/roadsides only, while 67.5 percent, 17.5 percent, and 15 percent of respondents were retailing avocado on open spaces/roadsides, plastic shelters, and houses, respectively (Figure 4). Less than 20 percent of respondents were only selling fruit and vegetables in houses/shops. Almost all fruits and vegetables were sold on the roadside and open places in the study area because of the absence of shaded and properly constructed fruit and vegetable selling places. Fresh horticultural commodities are highly vulnerable to injuries like mechanical damage because of their soft texture and high water content. When the harvested commodities are exposed to adverse environmental factors such as extreme temperature and dust during transportation and marketing, their tissues subsequently are softened and rapid invasion of postharvest pathogens are caused. Since the harvested fresh fruits and vegetables lack natural defense mechanisms in the tissue, the microorganisms in their tissue 
TABLE 3: Sources of the commodities.

\begin{tabular}{lcc}
\hline Sources of products & Frequency & Percentage \\
\hline Wholesalers & 6 & 15.0 \\
Producers & 4 & 10.0 \\
Both wholesalers and producers & 26 & 65.0 \\
Total & 40 & 100.0 \\
\hline
\end{tabular}

Source: own survey (2019).

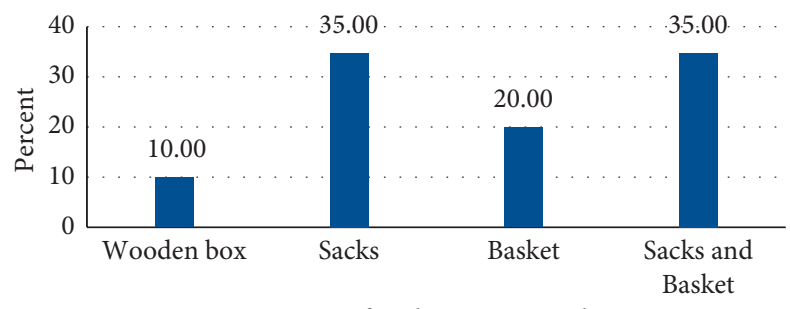

Types of packaging materials

Figure 2: Packaging materials used for fruits and vegetables, $n=40$.

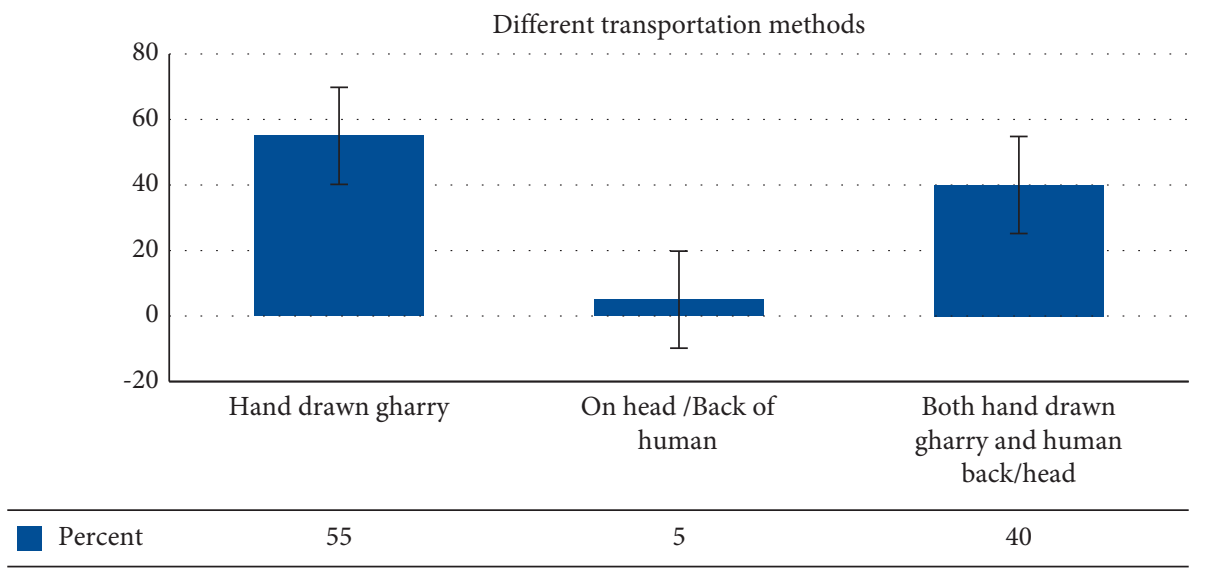

FIgURE 3: Percentage of respondents using different transportation methods $n=40$.

spread rapidly and ultimately make them unfit for consumption (Dugan et al., 2015). The present result is in agreement with the result of Adugna et al. (2013) who conducted the study in the Jimma zone.

\subsection{Type of Storage Material Used and Its Contribution to the} Loss. There is a significant difference $(p<0.001)$ between fruit and vegetable crops storage methods and materials. The present study reveals that $25 \%$ of fruit and vegetable retailers in the study area stored their produce separately while $75 \%$ of respondents stored different commodities together. In addition, $45 \%$ of respondents stored the commodities by covering a plastic sheet followed by a basket (30\%) and jute sack (20\%), while $5 \%$ of respondents were only storing their producers in the ventilated area (Table 4). Determining the proper storage method with minimum damage in quality and quantity and for better marketability and access of the fresh commodities, an efficient marketing system is essential.
Poor storage and packaging materials hasten senescence and the loss of quality [29]. Similar results were reported by Solomon [30].

3.8. Loss during Supply Chain and Its Fate. The present study revealed that there was a postharvest loss in fruits such as avocado, sweet orange, lime, banana, papaya, citron, and mango) and vegetables such as onion, kale, cabbage, pepper, Swiss chard, tomato, carrot, and potato during transit and storage. Harvested fruit and vegetable retailers dispose of overripe fruits as waste. A hundred percent of respondents explained that there is a loss during the marketing of harvested fresh commodities. The result also revealed that the majority of (45 percent) the damaged, wilted, and overripe fruits and vegetables were sold at a discount price (10-15 Ethiopian birr $/ \mathrm{kg}$ ) depending on their ripening stage for strays (homeless) and juice houses and in extreme case culled as waste material. However, 20 percent and 20 


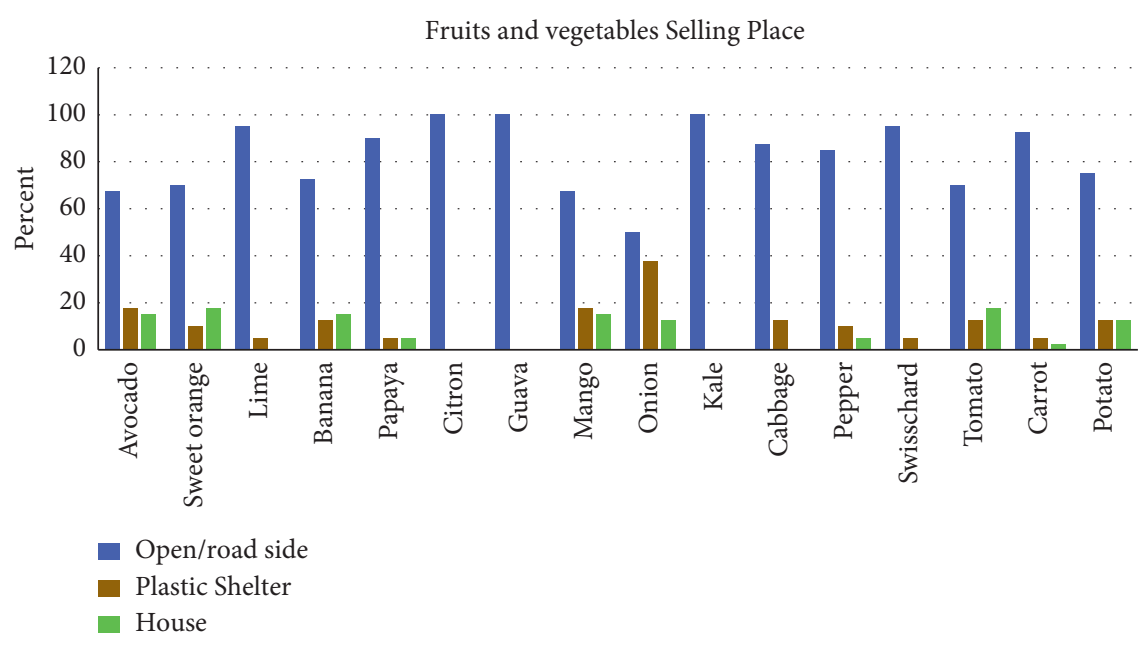

FIgURE 4: The percentage of selling fruits and vegetables at a market, $n=40$.

TABLE 4: Fruits and vegetables storage methods and storing materials.

\begin{tabular}{|c|c|c|c|c|}
\hline Questioners & Options & Frequency & Percentage & $X^{2}$ test \\
\hline \multirow{2}{*}{ Mixing different fruits and vegetables during storage } & Yes & 30 & 75.00 & \multirow{2}{*}{$10.00^{* *}$} \\
\hline & No & 10 & 25.00 & \\
\hline \multirow{4}{*}{ Storage material used } & Basket & 12 & 30.0 & \multirow{4}{*}{$13.6000^{* *}$} \\
\hline & Jute sack & 8 & 20.0 & \\
\hline & Ventilated room & 2 & 5.0 & \\
\hline & Covered by plastic & 18 & 45.0 & \\
\hline
\end{tabular}

Source: own survey (2019). ${ }^{* *}$ Significant difference at $p<0.01$.

percent, respectively, of respondents explained that they sold their damaged fruits and vegetables at lower prices alone and culling them as waste alone. While the remaining 15 percent of respondents were providing damaged, wilted, and overripe produce for animal fatteners to utilize as animal feed (Figure 5). Consuming extremely damaged produce may have a negative influence on human health and environmental safety also. According to Yigzaw et al. [25], instead of damping/culling damaged, wilted, and overripe fruits and vegetables everywhere, they might be used as animal feed in a scientific way and should be used as preparing compost to use plants as organic fertilizer and other energy sources. The present finding is in agreement with the report of Yigzaw et al. [25].

3.9. Knowledge on Postharvest Handling Practice. All (100 percent) respondents reported they do not have any formal knowledge on handling methods of harvest products and they did not receive any training on postharvest handling practices of fruits and vegetables except for the traditional knowledge that they have. They also reported that they are very interested in taking any training related to handling practices of harvested fresh commodities (Table 5). The majority of fruit and vegetable retailers in Debre Markos town have an educational background. This is a good opportunity to provide formal education and training related to postharvest handling activities to fill existing knowledge and skill gaps which in turn affect the horticulture subsector.

Sabo (2006) stated that, to enhance and adopt new technologies, education is an important variable. Therefore, there is a possibility to minimize fruit and vegetable postharvest loss in Debre Markos town through providing training and proving various postharvest technologies to retailers (zero energy or cooling chamber, establishing wellfurnished selling shops, etc.) to retailers. The present study is in line with the study of Zenebe et al. (2015) and Yigzaw et al. [25] who stated that fruit retailers in Ethiopia have very limited skill in physiology and handling practices of harvested fruit crops postharvest.

3.10. Loss after Harvest for Fruits and Vegetables in Different Chains. A significant difference $(p<0.001)$ was observed for loss after harvest for fruits and vegetables at the selling place and during transportation. The estimated average losses of the fruits and vegetables for retailers range from 5 percent to 83 percent depending on the commodity nature. The maximum percentage of total loss for all fruits and vegetables was observed for lime/lemon ( 83 percent) followed by tomato (30 percent) during marketing/selling and transportation. Among the fruit crops, the maximum postharvest loss (55 percent) was observed for lemon during marketing followed by banana (10 percent), guava ( 8 percent), and mango (8 percent). Among vegetables, the maximum 


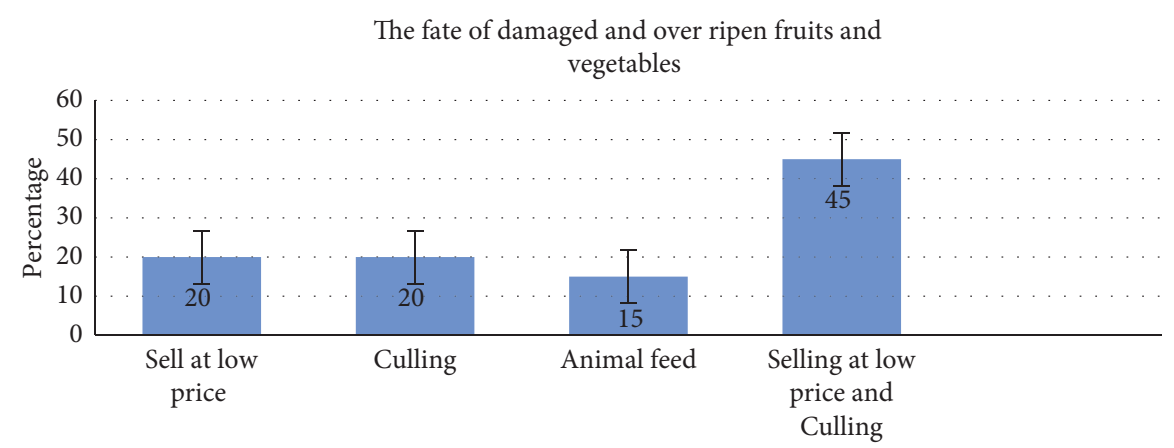

FIGURE 5: The fate of damaged and overripe fruits and vegetables, $n=40$.

TABLE 5: Knowledge of postharvest handling practices.

\begin{tabular}{lcc}
\hline & Frequency & Percentage \\
\hline No & 40 & 100.0 \\
Yes & 0 & 00 \\
\hline
\end{tabular}

Source: own survey (2019).

postharvest loss (18 percent) was observed for tomato during marketing followed by head cabbage (15 percent), pepper (10 percent), and carrot (14 percent). During transportation, the maximum postharvest loss (28 percent) was observed for lime followed by papaya ( 8 percent). From vegetable crops, the maximum postharvest loss during transportation was recorded for pepper and tomato (10 percent) each whereas relatively the lowest loss was observed for citron (3.5 and 1.5 percent during storage/marketing/selling and transportation, respectively) and sweet orange ( 4 and 2 percent during storage/marketing/selling and transportation, respectively). The present finding also indicated that the highest postharvest loss occurred during marketing compared with transportation in Debre Markos town (Table 6). This is because, during handling and marketing, fruits and vegetables are exposed to dust, high temperature, vehicle dust, and rain and are also infected with various hidden postharvest pathogens which may cause rotting during the postharvest management period. Additionally, the poor transportation method has played a significant role in both physiological and mechanical damage of fresh commodities and is an influencing factor for hastening postharvest loss in marketing/selling. Overload of vegetables and fruits during transit causes mechanical and physiological damage especially on poor roads leading to high heat generation and it may hasten their respiration rate which hastens deterioration. Additionally, poor packaging material during storage and transportation also reduces the storage period of fruits and vegetables. According to Sirivatanapa (2006), the maximum loss of harvested horticultural crops was recorded mostly during marketing, transport, and storage place and in some cases through the whole channel. This is due to the fact that fresh commodities after harvest continue the metabolic processes such as transpiration and respiration until their stored food and water are exhausted.

Relatively, the highest percentage of loss was observed from fruit crops compared with vegetable crops. Similar results were presented by Tadesse (1991) who revealed the more delicate and highly perishable types of produce (tomatoes, guava) were exposed to higher losses than the less perishable commodities (carrot, citrus fruits, and cabbage).

3.11. Major Causes of Postharvest Loss. The postharvest loss occurring at the retailer level in the study area is attributed to many reasons, from the mechanical damage during loading and unloading, bruising, mold growth, softening due to frequently touching by hand and pressing, wilting due to loss of moisture by transpiration, and marketing in improper way. Table 7 shows the types/causes of losses that occur during fruit and vegetable retailing and the result shows that rotting, mechanical damage, poor handling practices (storage, transportation, and marketing place), poor control of temperature and relative humidity, and hygiene problems are the major ones during handling of fruits and vegetables, respectively. Wilting of vegetable crops is the main problem of almost all retailers because the products are displayed in hot conditions without any modification of relative humidity and temperature and these result in high transpiration loss. Due to the loss of their water, the fruits lose their turgidity and shrink when they are stored for more than three or four days, as most retailers responded. The present result is also in agreement with [31].

3.12. Challenges of Fruit and Vegetable Retailers in Debre Markos. Postharvest handling practice is undertaken in the traditional method. Fruit and vegetable retailers have explained demands and major constraints/challenges in their marketing performance. Some of the major challenges are as follows:

(1) Absence of permanent and standard selling place.

(2) Poor marketing structure. 
TABLE 6: Fruits and vegetables postharvest losses extent.

\begin{tabular}{|c|c|c|c|c|}
\hline \multirow{2}{*}{ Commodity type } & \multicolumn{2}{|c|}{ Loss at storage/selling $(\mathrm{kg} / 100 \mathrm{~g})$} & \multicolumn{2}{|c|}{ Loss at transportation $(\mathrm{kg} / 100 \mathrm{~g})$} \\
\hline & Frequency & Percentage & Frequency & Percentage \\
\hline Avocado & 5 & 2.52 & 9 & 8.45 \\
\hline Sweet orange & 4 & 2.02 & 2 & 1.88 \\
\hline Lime & 55 & 27.71 & 28 & 26.29 \\
\hline Banana & 10 & 5.04 & 5 & 4.69 \\
\hline Papaya & 5 & 2.52 & 8 & 7.51 \\
\hline Citron & 3.5 & 1.76 & 1.5 & 1.41 \\
\hline Guava & 8 & 4.03 & 6 & 5.63 \\
\hline Mango & 8 & 4.03 & 10 & 9.39 \\
\hline Onion & 8 & 4.03 & 4 & 3.76 \\
\hline Kale & 10 & 5.04 & 0 & 0.00 \\
\hline Cabbage & 15 & 7.56 & 3 & 2.82 \\
\hline Pepper & 15 & 7.56 & 10 & 9.39 \\
\hline Swiss chard & 10 & 5.04 & 0 & 0.00 \\
\hline Tomato & 18 & 9.07 & 10 & 9.39 \\
\hline Carrot & 14 & 7.05 & 5 & 4.69 \\
\hline Potato & 10 & 5.04 & 5 & 4.69 \\
\hline$x^{2}$ & \multicolumn{2}{|c|}{$177.5403^{* *}$} & \multicolumn{2}{|c|}{$73.7582^{* *}$} \\
\hline
\end{tabular}

Source: own survey (2019). ${ }^{* *}$ Significant difference at $p<0.01$.

TABle 7: Causes of postharvest loss.

\begin{tabular}{|c|c|}
\hline Fruits & Type of major loss \\
\hline Avocado & Mechanical damage, softening, decay \\
\hline Sweet orange & Rupturing, shrivelling \\
\hline Lime & Overripe/fast ripening, softening \\
\hline Banana & Weight loss, blackening, mechanical damage, rotting \\
\hline Papaya & Decay, black spot, crash \\
\hline Citron & Bruising \\
\hline Mango & Softening, blackspot, mechanical damage \\
\hline \multicolumn{2}{|c|}{ Vegetable type of major loss } \\
\hline Onion & Decay, wilt, shrink, flaccid, sprouting \\
\hline Kale & Wilting, loss of green colour \\
\hline Cabbage & Bussing, colour change, wilting, mechanical damage \\
\hline Pepper & Bruising, decay, wilting, colour change \\
\hline Swiss chard & Wilting, loss of green colour \\
\hline Tomato & Decay, mechanical damage, blackspot \\
\hline Carrot & Mechanical damage, rotting \\
\hline Potato & Shrivelling, wounding during harvest, sprouting \\
\hline
\end{tabular}

Source: own field and laboratory observation (2019).

(3) Absence of simple storage technologies to maintain and prolong shelf life (cool chambered zero energy).

(4) Unavailability of well-established market infrastructure, lack of cooling and storage facilities.

(5) Poor transportation facilities.

(6) The low market price due to poor quality.

(7) Absence of small-scale processing industries.

(8) Lack of practical skills related to postharvest handling and temperature and relative humidity management.

The present finding are consistent with [32] and Muluken et al. [31].

\section{Summary and Conclusion}

The present study revealed a significant difference between sociodemographic factors, handling practices, and postharvest loss. Educational status, selling experience, and packaging material have a significant relationship with postharvest loss. A significant difference was obtained among the transportation methods used, the selling place, storage methods, and materials. The majority of retailers sold fruits and vegetables along the roadsides and in open places. All fruit and vegetable retailers do not have formal knowledge on postharvest management practices and they are very interested in taking any training related to postharvest loss and handling practices. The losses after harvest 
were observed and the average postharvest losses at the fruit and vegetable retailers were estimated to be $5-83$ percent of the total purchased products for sale depending on the commodity nature.

The important factors that contribute to fruits and vegetables loss were packaging materials used for storage and transportation, the place where fruits and vegetables are sold, educational status of handlers, rotting, mechanical damage, poor handling, poor control of temperature and relative humidity, and hygiene problems.

Generally, to reduce the existing high postharvest loss of fruit and vegetable crops and supply quality products for consumers throughout the year, sustainable multistakeholder's linkage with responsible bodies is required. The present study recommends the following intervention areas for the future. Fruit and vegetable permanent selling shade/area should be established to supply quality products for consumers and to increase the income of retailers. In addition, the application of simple evaporative cooling storage technologies such as zero energy or cooling chamber to maintain quality and extend the shelf life of perishable horticultural crops. Moreover, immediate attention needs to be given to creating awareness on innovative postharvest handling practice of fresh fruits and vegetables through providing training for producers, wholesalers, and consumers. Furthermore, infrastructures for fruit and vegetable crops such as storage, roads for transportation, and packaging should be established. At the same time, the government and other policymakers should also set precise rules and regulations regarding licensing of fruit and vegetable retailers.

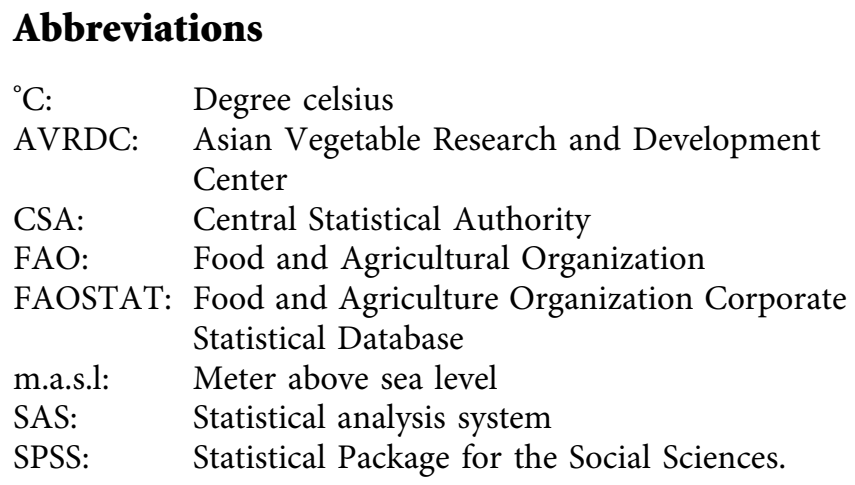

\section{Data Availability}

No data were used to support this study.

\section{Conflicts of Interest}

The authors declare that they have no conflicts of interest.

\section{Authors' Contributions}

YY and ET conceived the presented idea and performed analytical computations. Both the authors investigated the postharvest loss, verified the analytical methods, and reshaped the script and frameworks. Both authors read and approved the final manuscript.

\section{Acknowledgments}

The authors are grateful to the respondents of the study.

\section{References}

[1] D. Tilman, J. Fargione, B. Wolff et al., "Forecasting agriculturally driven global environmental change," Science, vol. 292, no. 5515, pp. 281-284, 2001.

[2] FAO, How to Feed the World in 2050, FAO, Rome, Italy, 2009.

[3] FAO, IFAD 2012 the State of Food Insecurity in the World 2012: Economic Growth Is Necessary but Not Sufficient to Accelerate the Reduction of Hunger and Malnutrition, FAO, Rome, Italy, 2014.

[4] FAOSTAT, "Production-fruits and vegetables in ethiopia," 2015, http://faostat3.fao.org/search/fruits\%20and\% 20vegetables/E.

[5] K. Weinberger and T. A. Lumpkin, "Diversification into horticulture and poverty reduction: a research agenda," World Development, vol. 35, no. 8, pp. 1464-1480, 2007.

[6] B. Emana and H. Gebremedhin, Constraints and Opportunities of Horticulture Production and Marketing in Eastern Ethiopia, p. 46, Dryland Coordination Group (DCG), Mekele, Ethiopia, 2007.

[7] T. Sebeko, "Assessment of postharvest loss for perishable produce from wholesalers to consumers. A case study of Etfruit distribution company in Addis Ababa, Ethiopia," Master's thesis, Swedish University of Agricultural Sciences, Uppsala, Sweden, 2015.

[8] CSA, The Federal Democratic Republic of Ethiopia. Agricultural Sample Survey. Report on Area and Production of Major Crops for Meher Season, CSA, Addis Ababa, Ethiopia, Statistical Bulletin No 586, 2018.

[9] S. Zorya, N. Morgan, R. L. Diaz et al., "Missing food: the case of postharvest grain losses in sub-saharan Africa," 2011.

[10] R. J. Hodges, J. C. Buzby, and B. Bennett, "Postharvest losses and waste in developed and less developed countries: opportunities to improve resource use," The Journal of Agricultural Science, vol. 149, no. S1, pp. 37-45, 2011.

[11] M. Madrid, "Reducing postharvest losses and improving fruit quality worldwide: the one-billion-dollar untapped business opportunity," 2011, http://www.fruitprofits.com/ing/articulo. asp?reg=26.

[12] A. A. Kader, "Increasing food availability by reducing postharvest losses of fresh produce," Acta Horticulturae, vol. 682, pp. 2169-2176, 2005.

[13] T. Garnett, Fruit and Vegetables and UK Greenhouse Gas Emissions: Exploring the Relationship, pp. 1-134, Food and Climate Research Network, University of Surrey, Guildford, UK, 2006.

[14] P. Salami, H. Ahmadi, A. Keyhani, and M. Mohammad Sarsaifee, "Strawberry post-harvest energy losses in Iran," Researcher, vol. 2, no. 4, pp. 67-73, 2010.

[15] Y. Yebirzaf, T. Esubalew, and W. Mahlet, "Utilization, cultivation practice and economic role of medicinal plants in Debre Markos town, East Gojjam zone, amhara region, Ethiopia," Journal of Medicinal Plants Research, vol. 13, no. 1, pp. 18-30, 2019.

[16] T. Yamane, Statistics, An Introductory Analysis, Harper and Row, Manhattan, NY, USA, 2nd edition, 1967.

[17] M. Masood, An Assessment of Apple Post-Harvest Losses, The Case of Nerkh District, Afghanistan, Vol. 10, Van Hall Larenstein University of Applied Sciences, Velp, Netherlands, 2011. 
[18] G. Abera, A. M. Ibrahim, S. F. Forsido, and C. G. Kuyu, "Assessment on post-harvest losses of tomato (Lycopersicon esculentem Mill.) in selected districts of East Shewa zone of Ethiopia using a commodity system analysis methodology," Heliyon, vol. 6, no. 4, Article ID e03749, 2020.

[19] M. Alemayehu, M. Abera, and S. Bizuayehu, "Determinants and extent of pre-and postharvest losses of fruits in Northwestern Ethiopia," International Journal, vol. 5, no. 4, pp. 68-75, 2018.

[20] G. A. Kereth, M. Lyimo, H. A. Mbwana, R. J. Mongi, and C. C. Ruhembe, "Assessment of post-harvest handling practices: knowledge and losses of fruits in bagamoyo district of Tanzania," Food Science and Quality Management, vol. 11, 2013.

[21] L. Kitinoja and M. Cantwell, "Identification of appropriate postharvest technologies for improving market access and incomes for small horticultural farmers in sub-saharan Africa and South Asia," WFLO Grant Final Report to the Bill \& Melinda Gates Foundation, Tempe, AZ, USA, 2010, http:// ucanr.edu/datastoreFiles/234-1848.pdf.

[22] M. M. Molla, "Survey on postharvest practices and losses of litchi in selected areas of Bangladesh," Bangladesh Journal of Agricultural Research, vol. 35, no. 3, pp. 439-451, 2010.

[23] L. Kitinoja and H. Y. AlHassan, "Identification of appropriate postharvest technologies for small scale horticultural farmers and marketers in sub-saharan Africa and South Asia-Part 1. Postharvest losses and quality assessments," Acta Horticulturae, vol. 934, no. 934, pp. 31-40, 2012.

[24] A. Debela, G. Daba, D. Bane, and K. Tolessa, "Identification of major causes of postharvest losses among selected fruits in Jimma zone for proffering veritable solutions," International Journal of Current Research, vol. 3, no. 11, pp. 40-43, 2011.

[25] D. Yigzaw, A. Habtemariam, D. Amare, and Amare Haileslassie, "Assessment of fruit postharvest handling practices and losses in Bahir Dar, Ethiopia," African Journal of Agricultural Research, vol. 11, no. 52, pp. 5209-5214, 2016.

[26] S. Hussein, H. Beshir, and Y. W. Hawariyat, "Postharvest loss assessment of commercial horticultural crops in South Wollo, Ethiopia "Challenges and opportunities"” Journal Food Science and Quality Management, vol. 17, 2013.

[27] A. A. Kader and R. S. Rolle, The Role of Post-harvest Management in Assuring the Quality and Safety of Horticultural Produce, FAO, Rome, Italy, 2004.

[28] M. U. Rehma, N. Khan, and I. Jan, "Post-harvest losses in tomato crop: a case of peshawar valley," Sarhad Journal of Agriculture, vol. 23, no. 4, 2007.

[29] AVRDC, Training Manual on Postharvest Research and Technology Development for Tomato and Chilli In Reta 6208 Countries; Improving Rural Livelihoods Through the Development of Vegetable-Based Postharvest Technologies, AVRDC, Tainan, Taiwan, 2006.

[30] S. Ali Gebeyehu, "Assessment of post-harvest losses of major fruit crops at East Gojjam zone, amhara region," Journal of Biology, Agriculture, and Healthcare, vol. 9, no. 1, 2019.

[31] M. Bantayehu, M. Alemayehu, M. Abera, and B. Solomon, "Postharvest losses assessment of tropical fruits in the market chain of North-Western Ethiopia," Food Science and Quality Management, vol. 66, 2017.

[32] M. I. Kaysar, M. S. Mia, M. S. Islam, and A. K. M. G. Kausar, "Postharvest loss assessment of brinjal in some selected areas of Bangladesh," International Journal of Business, Management and Social Research, vol. 2, no. 2, pp. 118-124, 2016. 